Jurnal Geocelebes Vol. 5 No. 1, April 2021, 35 - 45

\title{
PENGARUH DINAMIKA OSEANOGRAFI TERHADAP EKOSISTEM MANGROVE DI DESA PAGATAN BESAR
}

\author{
Ira Puspita Dewi*, Nursalam, Dimas Widyanata \\ Prodi Ilmu Kelautan Fakultas Perikanan dan Kelautan ULM, Jl. Jend. A. Yani Km. 36 Banjarbaru, Indonesia \\ *Corresponding author. Email: irapuspitadewi@ulm.ac.id
}

Manuscript received: 26 November 2020; Received in revised form: 24 March 2021; Accepted: 5 April 2021

\begin{abstract}
Abstrak
Ekosistem mangrove di pesisir Desa Pagatan Besar telah berkembang menjadi kawasan ekowisata mangrove yang membentang sepanjang $1 \mathrm{~km}$ di Pesisir Barat Desa Pagatan Besar. Desa Pagatan Besar dengan berbagai dinamika biofisiknya mempunyai potensi terjadinya perubahan bentang alam, yang umumnya dipengaruhi oleh gelombang dari Laut Jawa. Penelitian ini secara umum bertujuan (1) menganalisis riwayat gelombang maksimum 21 tahun, (2) menganalisis arus rata-rata selama 4 tahun terakhir, (3) mengamati pengaruh dinamika oseanografi terhadap perubahan garis pantai dan tutupan mangrove. Metode penelitian meliputi penelusuran literatur, pengumpulan data, pengolahan dan analisis data. Data gelombang diperoleh dari peramalan gelombang menggunakan data angin dari situs ECMWF dianalisis dengan plot series dan wave rose. Data arus diolah dengan metode least square pada software WTWC MATLAB untuk mengetahui pola distribusi arus total, pasang surut, dan residu setiap komponen arus. Analisis terhadap perubahan garis pantai dan tutupan mangrove menggunakan tumpang susun citra satelit Landsat tahun 1999, 2009 dan 2019. Hasil penelitian ini adalah (1) gelombang maksimum selama 21 tahun dominan terjadi pada Musim Barat (Desember - Februari) dengan ketinggian rata-rata 1,515 meter. Gelombang maksimum tertinggi terjadi pada tahun 2001 yaitu 2,03 meter, (2) Rata-rata kecepatan arus total pada Musim Barat mencapai 14,91 cm/s, arus pasut sebesar $13,88 \mathrm{~cm} / \mathrm{s}$ dan arus residu sebesar $6,17 \mathrm{~cm} / \mathrm{s}$, dengan pola dominan ke arah timur laut dan tenggara, (3) Terjadi perubahan garis pantai (sedimentasi dan abrasi) serta penurunan luasan mangrove sebesar 4,68 Ha selama periode 1999 - 2009.
\end{abstract}

Kata Kunci: arus; garis pantai; gelombang maksimum; mangrove; oseanografi

\begin{abstract}
The mangrove ecosystem on the coast of Pagatan Besar Village has developed into a mangrove ecotourism area that stretches $1 \mathrm{~km}$ along the west coast of Pagatan Besar Village. Pagatan Besar Village with its various biophysical dynamics has the potential for changes in the landscape, which are generally influenced by waves from the Java Sea. This study generally aims (1) to analyze the maximum wave history of 21 years, (2) to analyze the average current during the last 4 years, (3) to observe the effect of oceanographic dynamics on changes in shoreline and mangrove cover. The research method includes literature search, data collection, data processing and analysis. Wave data obtained from wave forecasting using wind data from the ECMWF site were analyzed by plot series and wave rose. Flow data were processed using the least square method in the WTWC MATLAB software to determine the distribution pattern of the total flow, tides, and residues of each current component. Analysis of changes in shoreline and mangrove cover using overlaying Landsat satellite imagery in 1999, 2009 and 2019. The results of this study are (1) the maximum waves for 21 years are dominant in the western season (December - February) with an average height of 1.515 meters. The highest maximum wave occurred in 2001, namely 2.03 meters, (2) The average total flow velocity in the west season reaches $14.91 \mathrm{~cm} / \mathrm{s}$,
\end{abstract}


tidal current is $13.88 \mathrm{~cm} / \mathrm{s}$ and residual current is $6.17 \mathrm{~cm} / \mathrm{s}$, with a dominant pattern towards the northeast and southeast, (3) There has been a change in the coastline (sedimentation and abrasion) and a decrease in mangrove area by 4.68 Ha during the 1999 - 2009 period..

Keywords: current; mangrove; maximum wave; oceanography; shoreline

\section{Pendahuluan}

Indonesia secara garis besar memiliki 13 ancaman bencana, baik di darat maupun di pesisirnya. Salah satu ancaman bencana terhadap pesisir yaitu ancaman terhadap gelombang ekstrim dan abrasi (PERKA BNPB, 2012). Desa Pagatan Besar dengan berbagai dinamika biofisiknya mempunyai potensi terjadinya perubahan bentang alam. Dulunya, wilayah ini mengalami abrasi yang cukup besar, mencapai 150 - 200 meter dari garis pantai selama rentang waktu tahun 1997 - 2006. Soendjoto dan Arifin (1999) dalam Primatianti (2002) menyatakan sejak tahun 1985 pantai sepanjang $800 \mathrm{~m}$ dan selebar $150 \mathrm{~m}$ tersebut diabrasi oleh gelombang pasang. Hasil diskusi dengan masyarakat (2019) bahwa abrasi pada musim gelombang besar (Oktober - Januari) mencapai lebih 2 meter dalam kurun waktu 1997 - 2001. Sebagian penduduk yang bermukim di pesisir mengalami dampak pengikisan pantai yang cukup parah.

Kestabilan pesisir pantai di wilayah ini dan Kalimantan Selatan pada umumnya dipengaruhi oleh gelombang dari Laut Jawa dan Selat Makassar. Tekanan akibat dinamika oseanografi yang berasal dari laut sangat mempengaruhi kerentanan pantai (Dewi dan Baharuddin, 2019). Tekanan ini dapat dikurangi dengan mempertahankan vegetasi yang tumbuh di sepanjang pesisir pantai, seperti mangrove. Secara fisik, hutan mangrove berfungsi sebagai pelindung pantai dari pengaruh gelombang laut. Secara ekologi, hutan mangrove menyediakan habitat bagi berbagai macam spesies karena fungsinya sebagai daerah asuhan (nursery ground), daerah pemijahan (spawning ground), serta tempat untuk mencari makan (feeding ground) bagi biota perairan yang terdapat di dalamnya (Bengen, 2004).

Ekosistem mangrove di pesisir Desa Pagatan Besar seluas 276,58 Ha yang tersebar di sepanjang pantai dan muara sungai (Ponaru, Syahdan dan Nursalam, 2017), dengan jenis mangrove yang ditemukan sebanyak 5 jenis (Setiawan, 2017). Desa Pagatan Besar telah berkembang menjadi kawasan lindung atau kawasan ekowisata mangrove yang membentang sepanjang $1 \mathrm{~km}$ di Pesisir Barat Desa Pagatan Besar. Kawasan ekowisata ini memiliki luas \pm 10 ha. Jenis mangrove yang terdapat di lokasi tersebut didominasi oleh jenis Avicennia alba dan $A$. marina (Nursalam, Syahdan dan Akbar, 2019). Sejak tahun 2015 masyarakat mulai aktif melakukan penanaman mangrove untuk merehabilitasi wilayah mangrove yang rusak.

Meskipun keberadaan ekosistem mangrove yang terbukti dapat melindungi pantai, tetapi ancaman terhadap gelombang besar/ ekstrim yang bisa mengakibatkan abrasi tetap saja ada. Apalagi, ekosistem mangrove tergolong dinamis karena dapat terus berkembang serta mengalami suksesi sesuai dengan perubahan tempat tumbuhnya, mangrove juga tergolong labil karena mudah sekali rusak dan sulit untuk pulih kembali (Arief, 2003).

Besarnya energi gelombang dipengaruhi oleh kondisi di sekitarnya dan akan mempengaruhi kedudukan garis pantai. Menurut Pratikto, Armino dan Suntoyo (1997), gelombang yang datang mendekati pantai cenderung mengepung tanjung, dan mengkonsentrasikan energinya di sisi muka dan samping tanjung tersebut. Perlindungan ekstra sangat diperlukan untuk daerah pantai yang memiliki bagian 
yang menjorok ke laut. Sementara di daerah teluk, garis pantai lebih panjang dibanding tanjung, energi gelombang cenderung disebar ke sepanjang garis pantai. Kerentanan merupakan suatu kondisi dari suatu komunitas atau masyarakat yang mengarah atau menyebabkan tidak mampunya dalam menghadapi ancaman bencana. Kerentanan ekosistem mangrove merupakan suatu gejala yang berpotensi menimbulkan ancaman kerusakan, kelangsungan hidup dan pertumbuhan mangrove.

Ruang lingkup penelitian ini adalah pengaruh dinamika osenografi selama 22 tahun terhadap perubahan luasan mangrove dan perubahan garis pantai di kawasan ekowisata Desa Pagatan Besar, yang nantinya akan digunakan untuk menentukan indeks kerentanan ekosistem mangrove terhadap ancaman gelombang ekstrim sebagai dasar menyusun rekomendasi untuk mitigasi bencana pesisir dan laut. Penelitian ini bertujuan untuk menganalisis riwayat kejadian gelombang maksimum selama 21 tahun (1999 - 2020), menganalisis arus rata-rata selama 4 tahun terakhir (2016 - 2020), mengamati pengaruh dinamika oseanografi terhadap perubahan garis pantai serta tutupan mangrove di Desa Pagatan Besar tahun 1999, 2009 dan 2019.

\section{Metode Penelitian}

Penelitian dilaksanakan pada tahun 2020 dengan lokasi kajian yaitu kawasan ekowisata mangrove di Desa Pagatan Besar Provinsi Kalimantan Selatan (Gambar 1). Metode penelitian meliputi penelusuran data sekunder, perolehan data angin dan data citra, pengolahan dan analisis data angin dan citra satelit. Alur penelitian ini dapat dilihat pada Gambar 2 berikut.

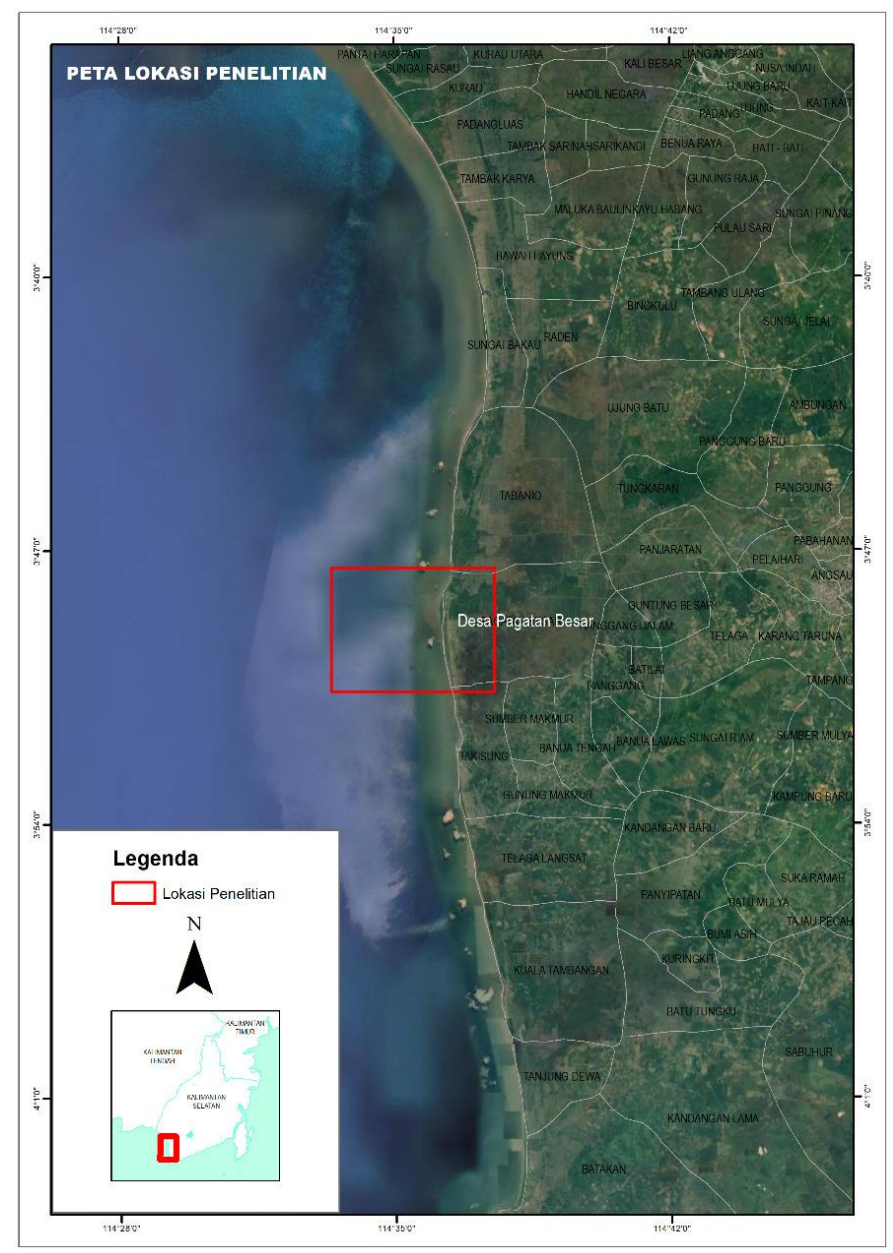

Gambar 1. Lokasi Penelitian. 


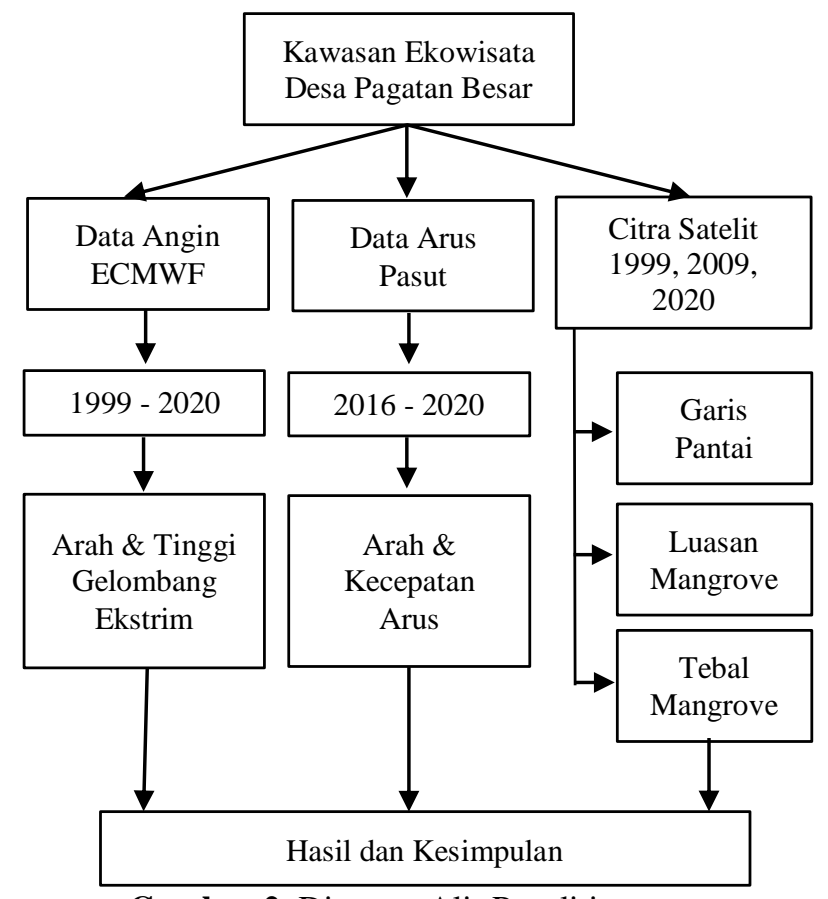

Gambar 2. Diagram Alir Penelitian.

\section{Perolehan Data}

Data gelombang ekstrim diperoleh dari Data Reanalysis ERA5 yang memiliki resolusi spasial sebesar $1^{\circ} \times 1^{\circ}$ dan resolusi temporal bulanan dari situs European Centre for Medium-Range Weather Forecasts (ECMWF) angin selama Januari 1999 - Juli 2020. Informasi data arus laut diperoleh melalui data instan yang diperoleh melalui situs http://marine.copernicus.eu dengan resolusi spasial $1 / 120(9,25 \mathrm{~km})$ pada koordinat lintang $3.75^{\circ} \mathrm{LS}$ dan $114.58^{\circ} \mathrm{BT}$. Arus yang diolah memiliki resolusi temporal 1 jam selama satu bulan di musim yang berbeda dan rataan bulanan pada tahun 2016 - 2020. Informasi perubahan garis pantai, luas tutupan mangrove serta kondisinya diperoleh dari citra satelit Landsat 7 dan Landsat 8 pada tahun 1999, 2009 dan 2019.

\section{Pengolahan dan Analisis Data}

Data dengan file ekstensi nc diekstrak menjadi format .txt menggunakan perangkat lunak Ocean Data View (ODV). Data gelombang dianalisis dengan plot series dan wave rose) dari tinggi gelombang selama 22 tahun diambil dari satu titik koordinat, yaitu titik $4^{\circ} \mathrm{LS}$ dan 114 ${ }^{\circ}$ BT. Hasil sebaran spasial gelombang berlokasi di Perairan Selatan Provinsi Kalimantan Selatan dengan domain wilayah sebesar $3-6^{\circ}$ LS dan $112-115^{\circ}$ BT berupa tinggi gelombang signifikan, tinggi gelombang maksimum dan arah rambatan gelombang. Plot series dan spasial gelombang dianalisis dengan menggunakan data interval 1 jam. Wave rose, tabulasi dan grafik dari kelas distribusi frekuensi rerata bulanan gelombang dianalisis menggunakan perangkat lunak WRPlot View.

Pada peramalan gelombang, kecepatan angin yang diperoleh dikonversi menjadi kecepatan angin di atas permukaan laut. Data angin yang digunakan dalam peramalan gelombang adalah data angin di atas permukaan laut sebagai tegangan angin (wind stress). Hasil peramalan gelombang yang terlalu besar perlu direduksi, maka dilakukan analisis fetch (Savile et al., 1962 dalam CERC, 1984).

Arus yang diperoleh merupakan total, arus total merupakan penjumlahan arus pasang surut dan arus non pasut (residu). Resolusi temporal 1 jam digunakan untuk memisahkan data arus pasang surut dengan arus residu. Arus total dipisahkan komponen timur - barat (u) dan komponen utara - selatan (v). Pengolahan data arus menggunakan metode least square yang disajikan pada software World Tide and World Current (WTWC) di MATLAB untuk mengetahui pola distribusi arus total, pasang surut, dan residu pada setiap komponen arus. Visualisasi data dilakukan dalam bentuk stickplot arus total, arus pasut, dan arus non pasut (residu).

Analisis perubahan garis pantai dan kondisi tutupan mangrove menggunakan citra satelit Landsat 7 dan Landsat 8 pada tahun 1999, 2009 dan 2019. Hasil analisis dari 3 tahun yang berbeda tersebut ditumpang 
susun untuk melihat dampak perubahan yang diakibatkan oleh dinamika oseanografi dalam hal ini gelombang dan arus terhadap perubahan garis pantai dan tutupan vegetasi mangrove.

\section{Hasil dan Pembahasan}

\section{Kejadian Gelombang Ekstrim 21 tahun (1999-2020)}

Tinggi gelombang maksimum dan gelombang signifikan selama 20 tahun memiliki nilai yang berfluktuatif. Tinggi gelombang maksimum memiliki rentang nilai $0,45-2,39 \mathrm{~m}$ (Gambar 3$)$ dengan nilai rerata tinggi gelombang sebesar $1,21 \mathrm{~m}$, sedangkan tinggi gelombang signifikan memiliki rentang nilai yang berkisar antara $0,03-1,19 \mathrm{~m}$ dengan rerata tinggi gelombang sebesar $0,42 \mathrm{~m}$. Tinggi gelombang maksimum dan gelombang signifikan tertinggi terjadi pada bulan September 2015 (Gambar 4).

Wave rose dan grafik distribusi gelombang maksimum pada Musim Barat disajikan pada Gambar 5. Arah gelombang maksimum pada Musim Barat dominan merambat menuju timur, arah lainnya menuju ke tenggara dan selatan dengan persentase yang lebih kecil. Resultan vektor wave rose bernilai $85 \%$ dengan arah 295 derajat (Gambar 5a). Grafik distribusi frekuensi gelombang (Gambar 5b) menunjukkan bahwa kelas tinggi gelombang yang mendominasi pada Musim Barat yaitu $1-2$ meter dengan nilai persentase sebesar $77,5 \%$, kelas tinggi gelombang $0-1$ meter memiliki persentase sebesar $21,2 \%$ dan kelas tinggi gelombang $2-3$ meter sebesar $1,3 \%$.

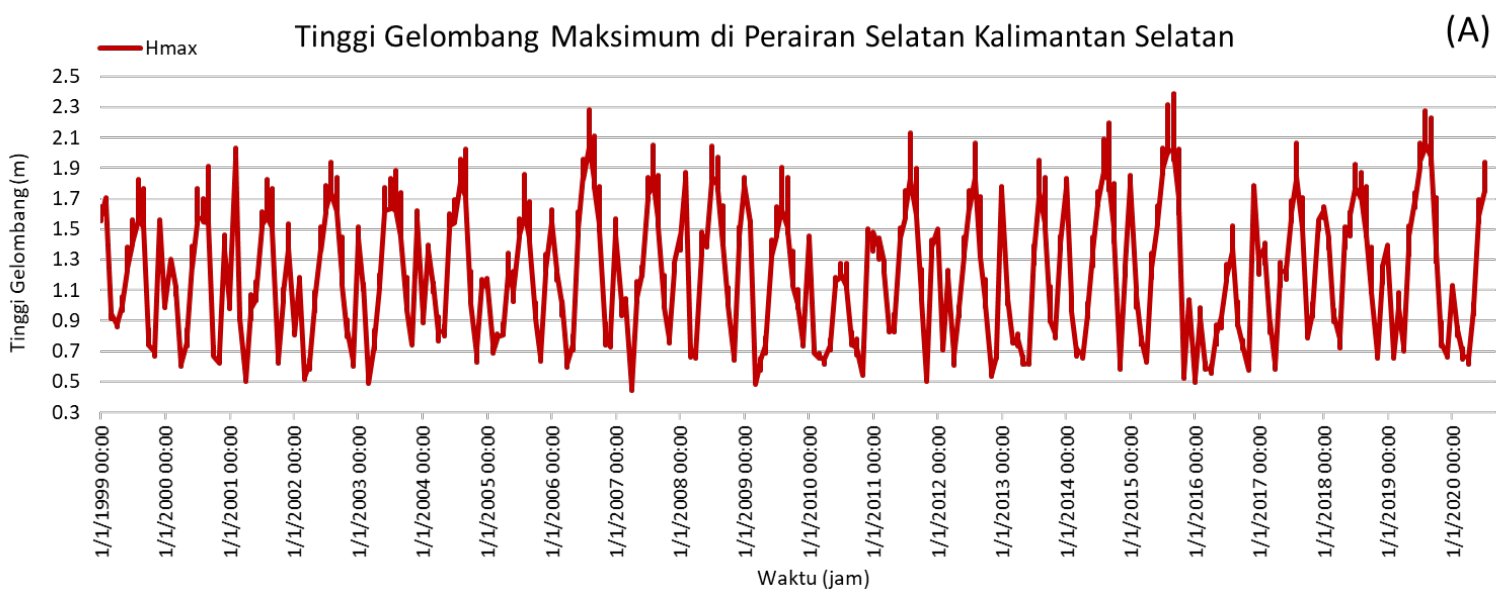

Gambar 3. Kejadian Gelombang Maksimum di Daerah Ekowisata Mangrove Desa Pagatan Besar selama 20 tahun.

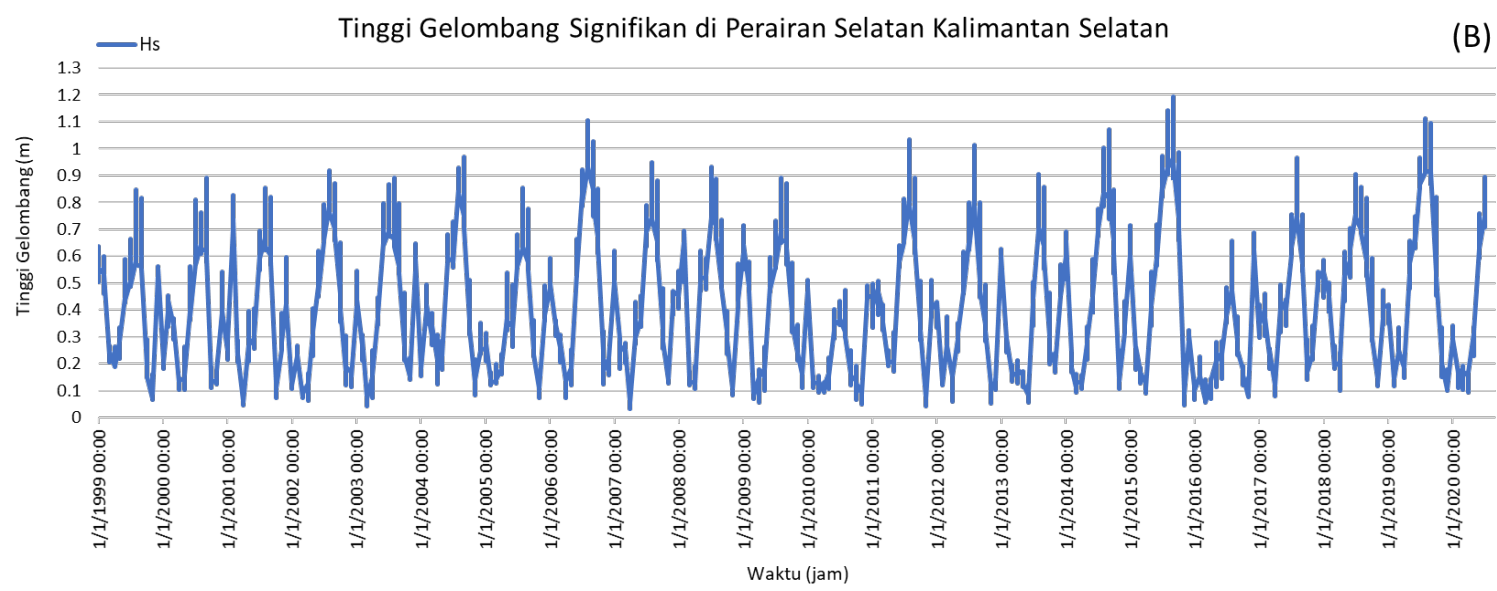

Gambar 4. Kejadian Gelombang Signifikan di Daerah Ekowisata Mangrove Desa Pagatan Besar selama 20 tahun. 


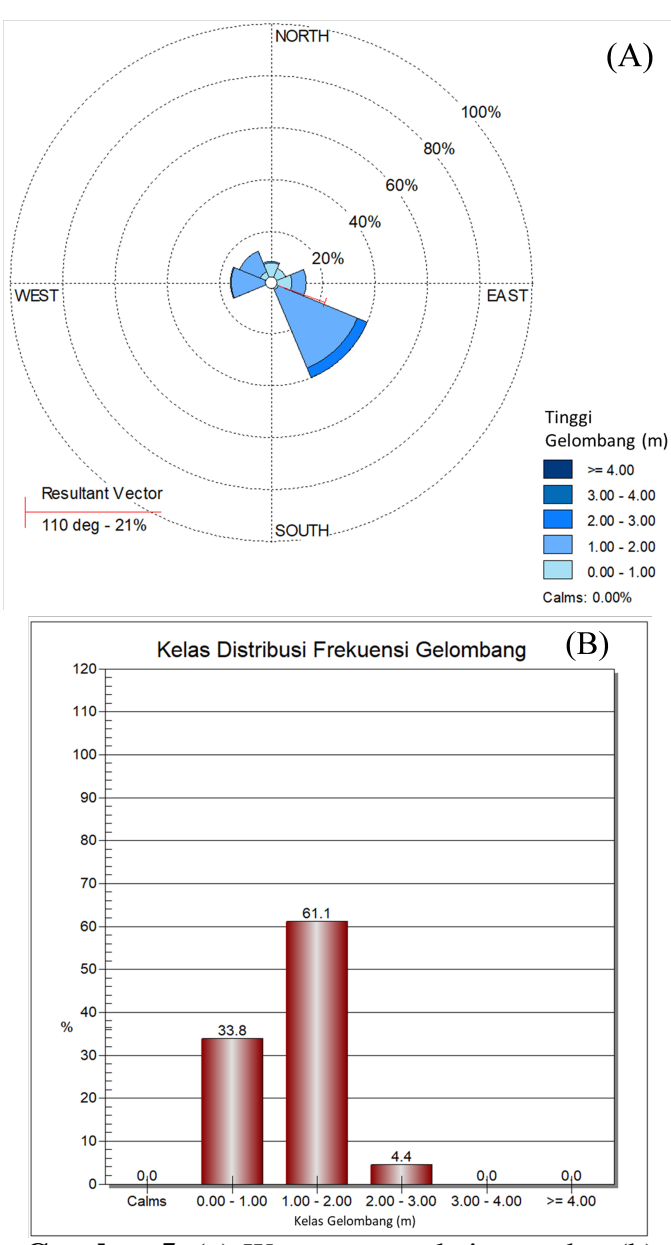

Gambar 5. (a) Wave rose maksimum dan (b) distribusi frekuensi gelombang (Januari 1999 - Juli
Tabulasi kelas distribusi frekuensi gelombang maksimum pada Musim Barat. Arah yang dominan pada Musim Barat adalah arah barat, dengan nilai presentase total sebesar $53,27 \%$, yang didominasi oleh kelas tinggi gelombang maksimum $1-2$ meter dengan persentase sebesar $48,97 \%$.

Berdasarkan Gambar 5 di atas dapat diketahui gelombang yang mempengaruhi kerentanan pantai di Desa Pagatan Besar adalah yang berasal dari barat dan barat daya, orientasi pantai desa ini menghadap ke arah barat. Pada Tabel 1 dapat dilihat data kejadian gelombang maksimum per tahun dominan terjadi di Musim Barat antara bulan Desember hingga Februari. Selama 20 tahun ketinggian gelombang maksimum rata-rata 1,515 meter. Gelombang maksimum tertinggi terjadi pada tahun 2001 yaitu 2,03 meter. Tinggi gelombang $1-2,5$ meter dikategorikan sebagai salah satu ancaman terhadap vegetasi mangrove (PERKA BNPB, 2012).

Tabel 1. Gelombang Maksimum Tahunan (Musim Barat) di Desa Pagatan Besar

\begin{tabular}{cccc}
\hline Tahun & H max (meter) & Waktu Kejadian & Keterangan \\
\hline 1999 & 1,709 & Jan-99 & Musim Barat \\
2000 & 1,302 & Feb-00 & Musim Barat \\
2001 & 2,03 & Feb-01 & Musim Barat \\
2002 & 1,166 & Feb-02 & Musim Barat \\
2003 & 1,514 & Jan-03 & Musim Barat \\
2004 & 1,378 & Feb-04 & Musim Barat \\
2005 & 1,17 & Jan-05 & Musim Barat \\
2006 & 1,619 & Jan-06 & Musim Barat \\
2007 & 1,565 & Jan-07 & Musim Barat \\
2008 & 1,856 & Feb-08 & Musim Barat \\
2009 & 1,837 & Jan-09 & Musim Barat \\
2010 & 1,5 & Dec-10 & Musim Barat \\
2011 & 1,477 & Jan-11 & Musim Barat \\
2012 & 1,5 & Jan-12 & Musim Barat \\
2013 & 1,775 & Jan-13 & Musim Barat \\
2014 & 1,833 & Jan-14 & Musim Barat \\
2015 & 1,853 & Jan-15 & Musim Barat \\
2016 & 1,784 & Dec-16 & Musim Barat \\
2017 & 0,984 & Feb-17 & Musim Barat \\
2018 & 1,926 & Feb-18 & Musim Barat \\
2019 & 1,392 & Jan-19 & Musim Barat \\
2020 & 1,134 & Jan-20 & Musim Barat \\
\hline Rerata & $\mathbf{1 , 5 1 5}$ & & \\
\hline
\end{tabular}




\section{Arus Laut (2016 - 2019)}

Pola arus total, pasang surut dan residu disajikan pada Musim Barat (Gambar 6) dan Musim Timur (Gambar 7). Arus Musim Barat memiliki pola dominan ke arah timur laut dan tenggara yang ditunjukan pada Gambar 6(a). Rata-rata kecepatan arus total pada Musim Barat $14,91 \mathrm{~cm} / \mathrm{s}$, arus pasut sebesar $13,88 \mathrm{~cm} / \mathrm{s}$ dan arus residu sebesar $6,17 \mathrm{~cm} / \mathrm{s}$. Musim Timur menunjukan pola arus dominan ke arah barat daya dan barat laut yang ditunjukan pada Gambar 7(a). Musim Timur memiliki rata-rata kecepatan arus total $14,27 \mathrm{~cm} / \mathrm{s}$, arus pasut sebesar 14,04 $\mathrm{cm} / \mathrm{s}$ dan arus residu sebesar $3,00 \mathrm{~cm} / \mathrm{s}$. Perbandingan rata-rata arus pasang surut dengan residu pada Musim Barat atau pun
Timur menunjukan arus pasang surut yang lebih dominan dibandingkan arus residu. Arus di kawasan ekowisata mangrove lebih dominan dipengaruhi oleh arus pasang surut, terlihat pada Gambar 6 dan Gambar 7 , pola arus total menyerupai pola arus pasang surut dibandingkan arus residu. Arus yang menunjukan pola fluktuatif mengikuti pola pasang surut, maka arus pasang surut merupakan arus yang dominan di perairan tersebut (Thurmann, 2007). Pola stickplot arus bulanan ditunjukan pada Gambar 8, terdapat perbedaan arah arus yang terjadi pada setiap bulan. Pada Musim Barat (Desember - Februari) pola arus dominan bergerak ke arah tenggara dengan rata-rata arus dan arus maksimum bulanan tertinggi terjadi pada bulan Desember sebesar $11,31 \mathrm{~cm} / \mathrm{s}$ dan $12,88 \mathrm{~cm} / \mathrm{s}$.
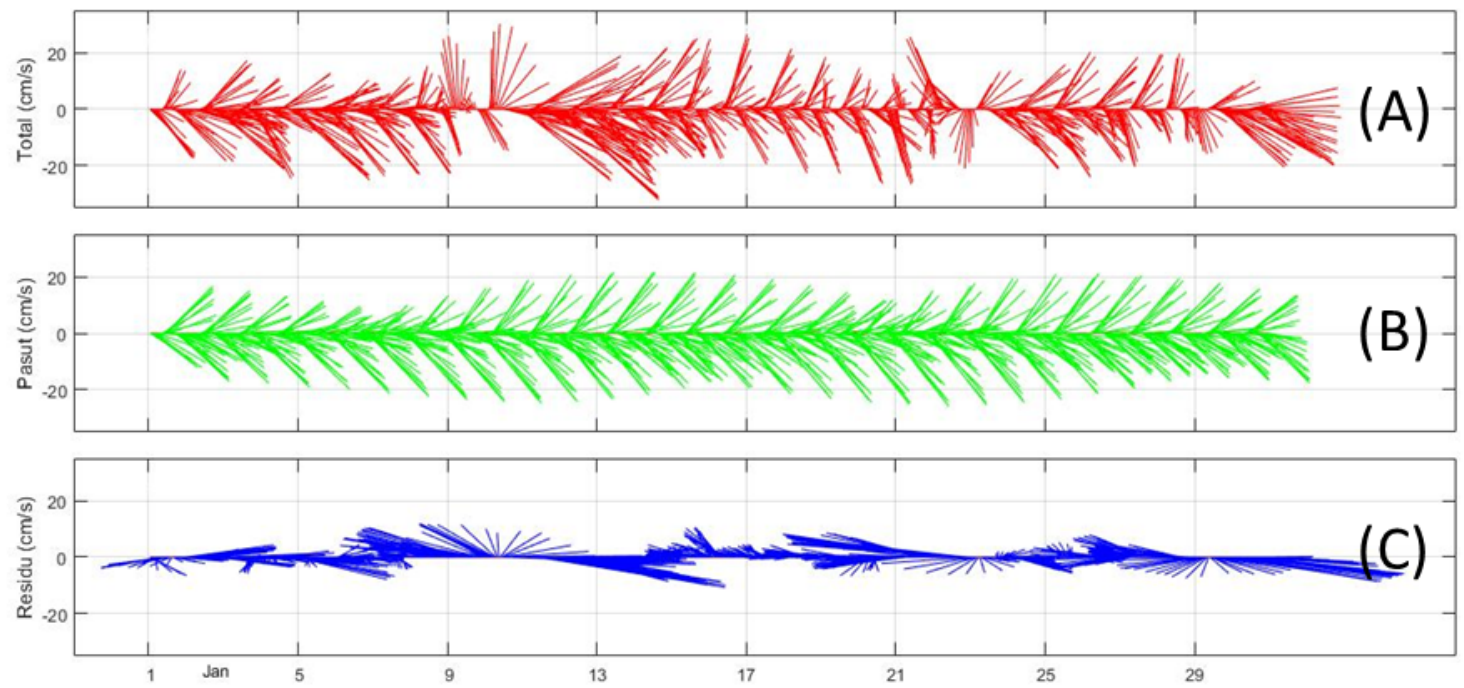

Gambar 6. (a) Arus Total, (b) Arus Pasang Surut, dan (c) Arus Residu Musim Barat.
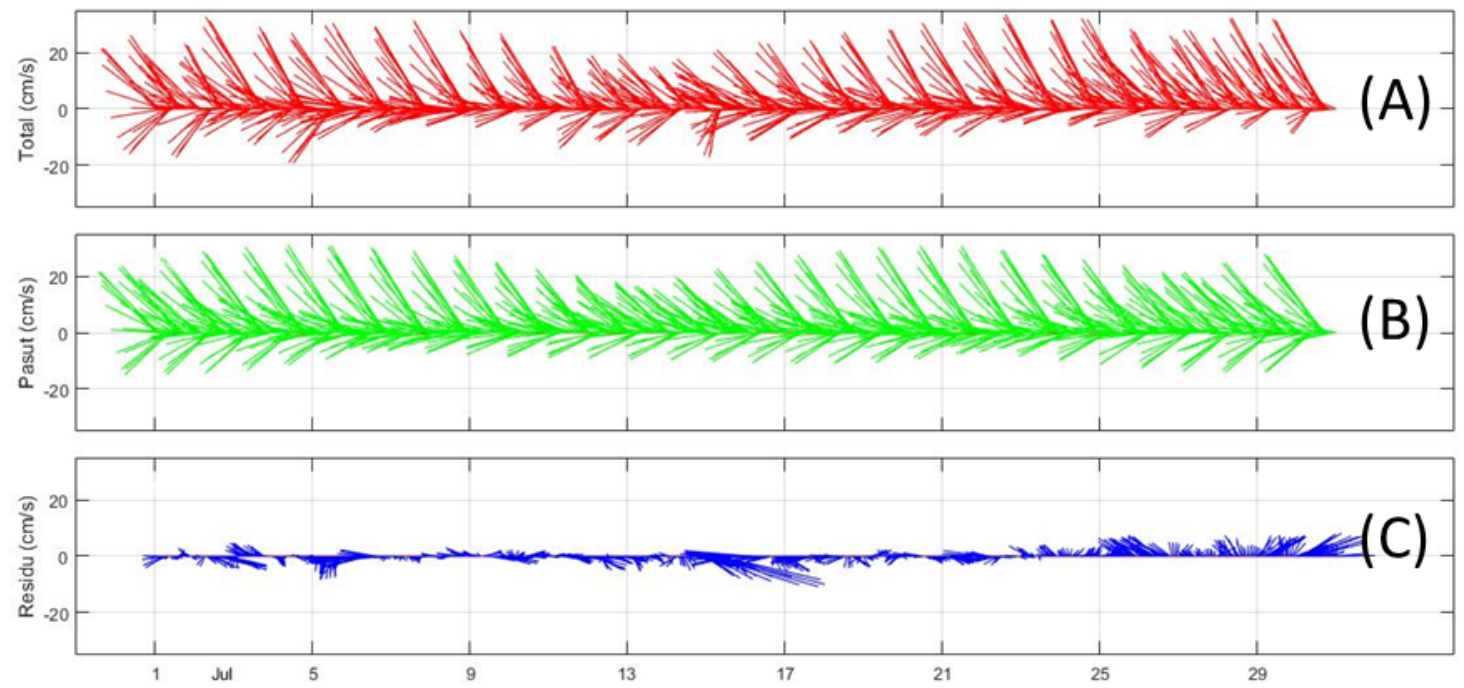

Gambar 7. (a) Arus Total, (b) Arus Pasang Surut, dan (c) Arus Residu Musim Timur. 

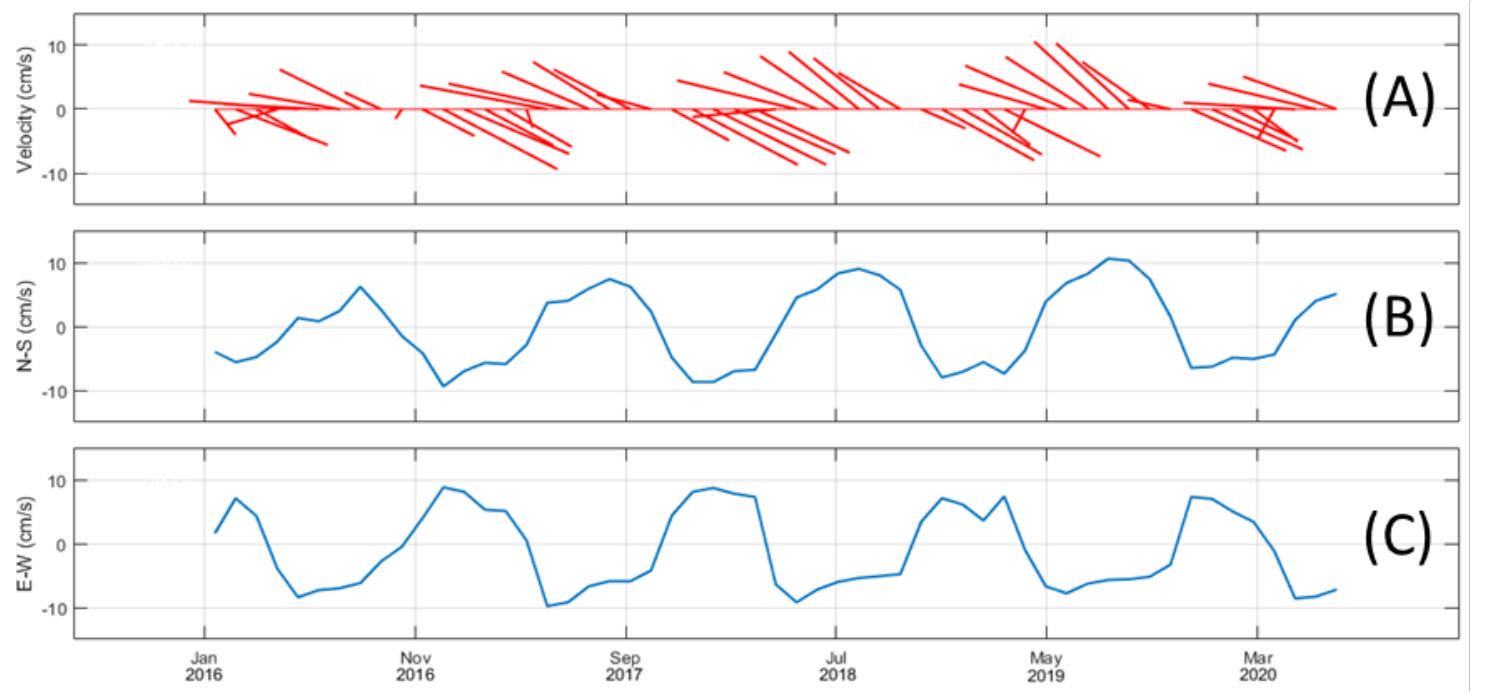

Gambar 8. Stickplot Arus (A), Arus Zonal (B), dan Meridional (C) Bulanan Tahun 2016 - 2020.

Pada musim peralihan I (Maret - Mei) terdapat perbedaan arah arus pada setiap bulannya yang cenderung menuju arah Barat atau menjauhi pantai. Arus rata-rata dan arus maksimum bulanan tertinggi terjadi pada bulan Mei sebesar 9,28 cm/s dan $10,48 \mathrm{~cm} / \mathrm{s}$. Sedangkan pada Musim Timur (Juni - Agustus) menunjukan pola arus dominan ke arah barat laut dengan kecepatan arus rata-rata dan arus maksimum bulanan tertinggi berada pada bulan agustus sebesar 10,19 cm/s dan 12,04 $\mathrm{cm} / \mathrm{s}$. Arus pada musim Peralihan II memiliki arah yang berbeda setiap bulannya, dengan kecepatan arus rata-rata dan arus maksimum bulanan tertinggi terjadi pada bulan September dengan nilai $8,40 \mathrm{~cm} / \mathrm{s}$ dan $11,72 \mathrm{~cm} / \mathrm{s}$ ke arah barat laut.

\section{Bentuk dan Perubahan Garis Pantai (1999, 2009 dan 2019)}

Bentuk garis pantai kawasan ekowisata mangrove Desa Pagatan Besar ada yang mengalami penambahan, tetapi dominan berkurang di beberapa titik (Tabel 2 dan Gambar 9) berdasarkan analisis citra satelit tahun rekam 1999, 2009 dan 2020. Garis pantai pada titik $\mathrm{A}, \mathrm{B}$ dan $\mathrm{C}$ berubah dan bertambah dengan jarak yang cukup tebal dengan variasi jarak $60-120$ meter. Sedangkan pada titik C, D dan E cenderung berkurang (abrasi) dengan jarak rata-rata 30 meter. Bentuk garis pantai yang lurus seperti pada pesisir kawasan ini rentan mengalami pengerusan (abrasi) oleh arus menyusur pantai maupun tegak lurus pantai.

Tabel 2. Perubahan Garis Pantai Hasil Tumpang Susun Tahun 1999, 2009 dan 2020

\begin{tabular}{cccl}
\hline Lokasi & Tahun & Jarak $(\mathbf{m})$ & Keterangan \\
\hline A & 1999 ke 2020 & 90 & Bertambah \\
B & 2009 ke 2020 & 120 & Bertambah \\
& 1999 ke 2009 & 60 & Bertambah \\
C & 1999 ke 2009 & 30 & Berkurang \\
& 2009 ke 2020 & 30 & Berkurang \\
D & 1999 ke 2009 & 30 & Berkurang \\
& 2009 ke 2020 & 30 & Berkurang \\
E & 1999 ke 2009 & 30 & Berkurang \\
& 2009 ke 2020 & 30 & Berkurang \\
\hline
\end{tabular}

Sumber: Hasil Analisis (2020) 


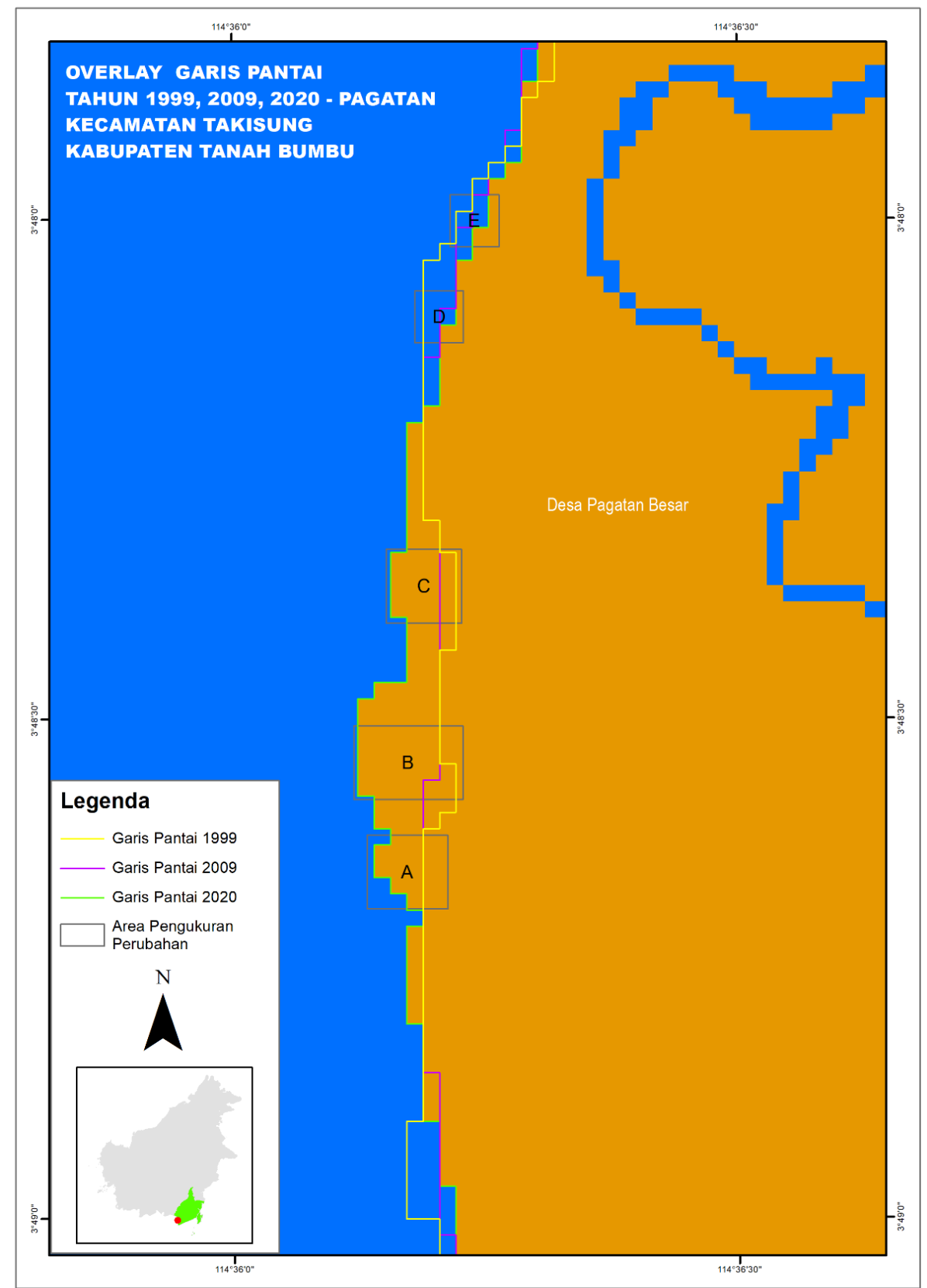

Gambar 9. Perubahan Garis Pantai Hasil Tumpang Susun Tahun 1999, 2009 dan 2020.

\section{Perubahan Tutupan Vegetasi Mangrove}

Kondisi ekosistem mangrove berdasarkan hasil komposit dan analisis citra satelit Landsat 7 dan 8 didapatkan bahwa luas tutupan mangrove pada tahun 1999 mencapai 9,36 ha, namun pada tahun 2009 menurun drastis menjadi 4,68 ha. Hal ini merupakan dampak akibat terjadinya gelombang ekstrim di wilayah tersebut. Daerah ekowisata mangrove ini rawan abrasi karena bentuk geomorfologi pantai yang lurus dan berada di bagian Selatan pantai Kalimantan Selatan yang berhadapan langsung dengan Laut Jawa, dengan orientasi pantai menghadap ke barat seperti terlihat pada Gambar 10.

Hasil penelurusan masyarakat dan hasil analisis riwayat kejadian gelombang, bahwa dalam kurun waktu 1997 - 2001 terjadi gelombang ekstrim mencapai lebih 2 $\mathrm{m}$ yang menyebabkan abrasi. Hal tersebut dipengaruhi oleh terjadinya anomali iklim global di laut atau kejadian El Nino dan La Lina di Samudera Pasifik. 


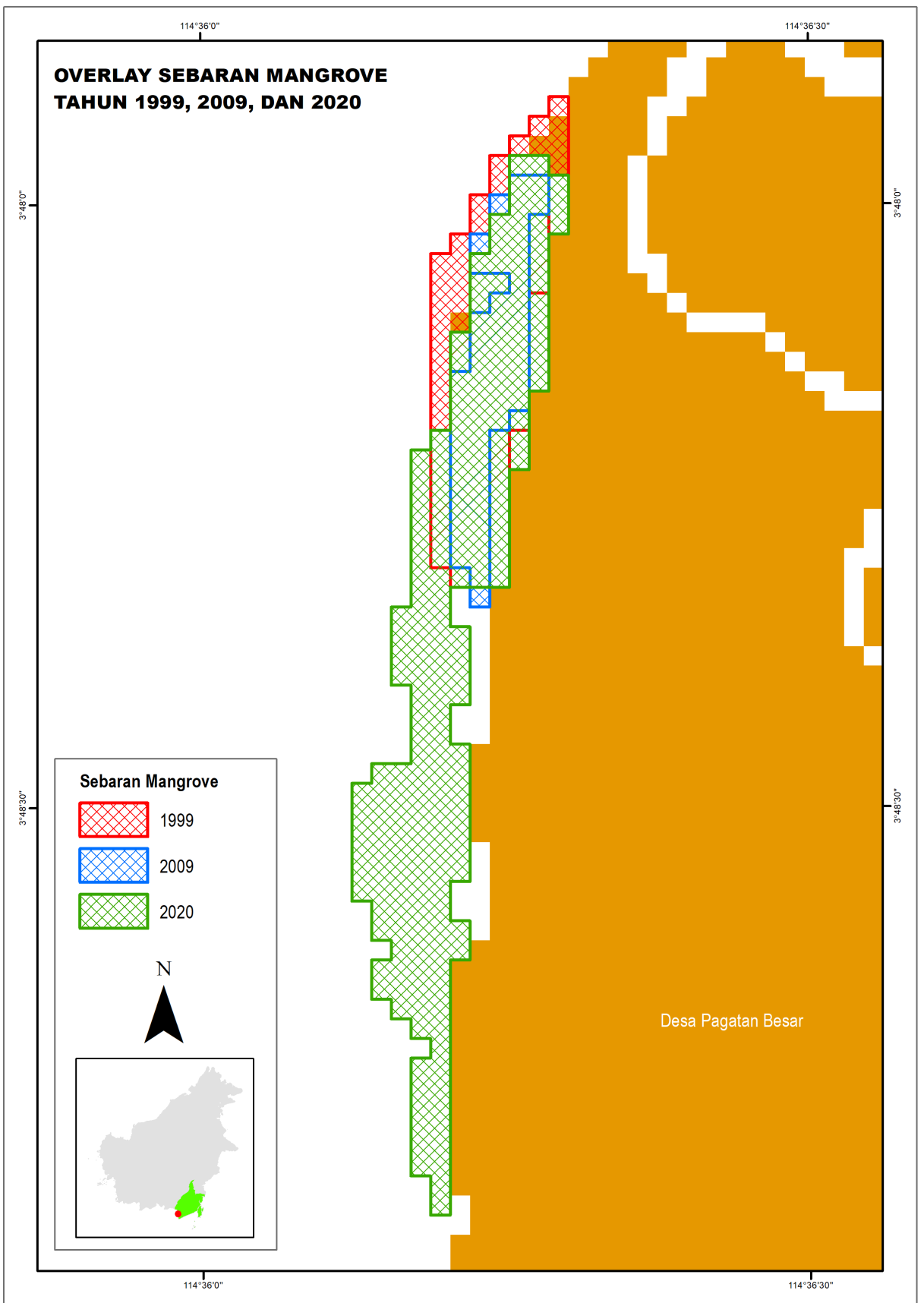

Gambar 10. Hasil perubahan sebaran/ tutupan mangrove dan ketebalan vegetasi mangrove selama 21 tahun (2019 - 2020) di Desa Pagatan Besar.

Tabel 3. Perubahan Luas Tutupan Mangrove di Kawasan Ekowisata Desa Pagatan Besar

\begin{tabular}{ccc}
\hline No & Tahun Rekam & Luas (Ha) \\
\hline 1 & 1999 & 9,36 \\
2 & 2009 & 4,68 \\
3 & 2020 & 18,27 \\
\hline \multicolumn{2}{l}{ Sumber: Hasil analisis citra Landsat 7 dan 8 (2020) }
\end{tabular}

Namun demikian, tutupan mangrove di tahun 2020 mengalami peningkatan luas tutupan menjadi 18,27 Ha (Tabel 3). Hal ini menunjukan sebagian kawasan ekowisata mangrove Desa Pagatan Besar mengalami pertumbuhan sekunder yang signifikan karena melalui hasil rehabilitasi.

\section{Kesimpulan}

Gelombang maksimum selama 20 tahun di Desa Pagatan Besar dominan terjadi pada musim barat di bulan Desember hingga Februari dengan ketinggian rata-rata 1,515 meter. Gelombang maksimum tertinggi 
terjadi pada tahun 2001 yaitu 2,03 meter. Rata-rata kecepatan arus total $2016-2020$ pada Musim Barat mencapai 14,91 cm/s, arus pasut sebesar $13,88 \mathrm{~cm} / \mathrm{s}$ dan arus residu sebesar $6,17 \mathrm{~cm} / \mathrm{s}$, dengan pola dominan ke arah timur laut dan tenggara. Terjadi perubahan garis pantai (sedimentasi dan abrasi) serta penurunan luasan mangrove sebesar 4,68 Ha selama periode 1999 - 2009.

\section{Ucapan Terima Kasih}

Terima kasih kepada Rektor Universitas Lambung Mangkurat, LPPM ULM, Dekan FPK ULM, Kepala Desa Pagatan Besar, Tim Peneliti serta masyarakat Desa Pagatan Besar yang telah mendanai dan membantu kelancaran penelitian ini.

\section{Daftar Pustaka}

Arief, A. 2003. Hutan Mangrove Fungsi dan Manfaatnya. Yogyakarta. Kanisius.

Bengen, G.D. 2004. Pedoman Teknis Pengenalan dan Pengelolaan Ekosistem Mangrove. PKSPL-IPB. Bogor.

[CERC] Coastal Engineering Research Center. 1984. Shore Protection Manual Volume I, Fourth Edition. Washington: U.S. Army Coastal Engineering Research Center.

Dewi, I.P. dan Baharuddin. 2019. Analisis Indeks Kerentanan Pantai Kalimantan Selatan. Seminar Nasional Perikanan dan Kelautan Tahun 2019. Fakultas Perikanan dan Kelautan. Universitas Lambung Mangkurat. Banjarbaru.

Nursalam., Syahdan, M., Akbar, Z. 2019. Kandungan Biomassa pada Struktur Tegakan Mangrove Jenis Avicennia marina di Desa Pagatan Besar. Makalah Seminar Nasional Perikanan dan Kelautan VI. Banjarbaru.

[PERKA BNPB] Peraturan Kepala Badan Nasional Penanggulangan Bencana
Nomor 02 Tahun 2012 Tentang Pedoman Umum Pengkajian Risiko Bencana.

Ponaru., Syahdan, M. dan Nursalam. 2017. Pemantauan Sebaran dan Luasan Vegetasi Mangrove Menggunakan Citra Landsat di Pesisir Kabupaten Tanah Laut. Jurnal MCSIJ. 1(1).

Pratikto, W.A., Armino, H.D. dan Suntoyo. 1997. Perencanaan fasilitas pantai dan laut. Edisi pertama. Bpfe. Yogyakarta. $226 \mathrm{hlm}$.

Primatianti, M. 2002. Kajian Partisifasi Masyarakat Dalam Pengelolaan Ekosistem Mangrove (Studi Kasus di Kecamatan Kintap dan Kecamatan Takisung, Kabupaten Tanah Laut Provinsi Kalimantan Selatan). Tesis. IPB. Bogor.

Setiawan, M.A.N. 2017. Analisis Vegetasi Mangrove dan Hubungannya dengan Parameter Lingkungan di Kecamatan Takisung Kabupaten Tanah Laut. Jurnal MCSIJ. 1(1).

Thurmann, H.V. 2007. Introductory Oceanography. Bell and Howell Company Columbus Ohio. 